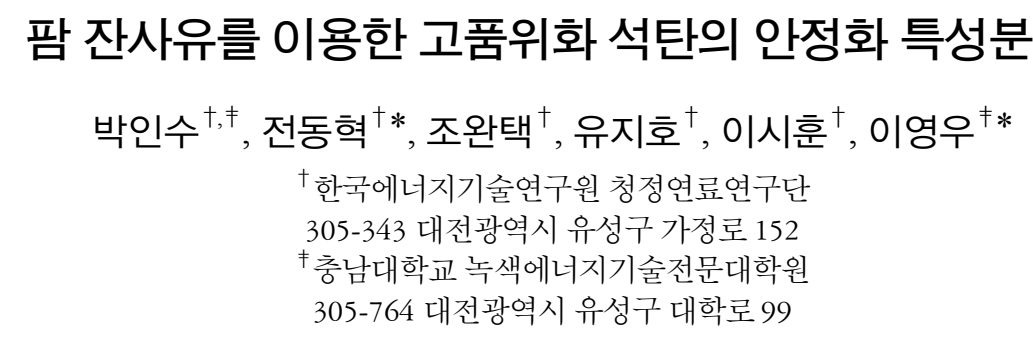

(2013년 9월 9일 접수; 2013년 10월 1일 수정본 접수; 2013년 10월 1일 채택)

\title{
Stabilization Characteristics of Upgraded Coal Using Palm Oil Residues
}

\author{
In Su Park ${ }^{\dagger, \neq}$, Dong Hyuk Chun ${ }^{\dagger} *$, Wan Taek Jo ${ }^{\dagger}$, Ji Ho You ${ }^{\dagger}$ \\ Si Hyun Lee ${ }^{\dagger}$, and Young Woo Rhee ${ }^{\ddagger} *$ \\ ${ }^{\dagger}$ Clean Fuel Center, Korea Institute of Energy Research \\ 152 Gajeong-ro, Yuseong-gu, Daejeon 305-343, Korea \\ ${ }^{\ddagger}$ Graduate School of Green Energy Technology, Chungnam National University \\ 99 Daehak-ro, Yuseong-gu, Daejeon 305-764, Korea
}

(Received for review September 9, 2013; Revision received October 1, 2013; Accepted October 1, 2013)

\section{요 약}

본 연구에서는 팜 잔사유를 이용하여 고품위화된 저등급 석탄의 건조 안정화 특성을 알아보았다. 인도네시아 저등급 석탄 인 에코탄을 사용하였고, 팜지방산증류물(palm fatty acid distillate, PFAD)을 혼합시킨 후 $107{ }^{\circ} \mathrm{C}$ 질소분위기에서 건조하였 으며 그 후에 안정화 특성을 평가하였다. 교차점온도(crossing-point temperature, CPT) 측정을 통해 자연발화 경향을 확인하 였으며, 저온산화 실험을 통해 $\mathrm{CO}_{2}, \mathrm{CO}$ 가스 배출량은 건조석탄보다 고품위 석탄이 감소하는 것을 확인하였다. 수분 재흡 착 실험을 통해 고품위 석탄이 대기방치와 항온항습 분위기에서 수분 재흡착이 줄어드는 것을 확인하였다. 고품위화된 석 탄은 PFAD의 표면코팅을 통해 안정화 되며, 함량이 증가할수록 안정화도가 높아졌다.

주제어 : 팜지방산증류물, 저등급석탄, 저온산화, 자연발화, 수분재흡착

\begin{abstract}
In this research, the stabilization characteristics of upgraded coal using palm oil residues were investigated. The Eco coal, which is the Indonesian low-rank coal, was used as a raw material. The low-rank coal was mixed with palm fatty acid distillate (PFAD), and then dried in a nitrogen atmosphere at $107^{\circ} \mathrm{C}$. The trend of spontaneous combustion of upgraded coal was studied by measuring of crossing-point temperature (CPT), low temperature oxidation and moisture readsorption. The results of the CPT measuring and low temperature oxidation showed that the propensity of spontaneous combustion of the upgraded coal was improved compared to the dried coal. The moisture readsorption characteristics of the upgraded coal was also improved. The upgraded coal was stabilized through the surface coating with PFAD, and stability of upgraded coal was proportional to the content of PFAD.
\end{abstract}

Keywords : Palm fatty acid distillate (PFAD), Low-rank coal, Low-temperature oxidation, Spontaneous combustion, Moisture readsorption

\section{1. 서 론}

저등급 석탄은 전세계적으로 분포되어 있으며 다른 화석연 료에 비해 값이 싸다는 장점이 있지만, 고 수분 및 저 발열량이

\footnotetext{
* To whom correspondence should be addressed.

E-mail: cian@kier.re.kr, ywrhee@cnu.ac.kr
}

doi:10.7464/ksct.2013.19.4.469
기 때문에 사용이 제한되어 왔다. 하지만 최근 고유가 및 고등 급 석탄의 수요가 증가함에 따라 저등급 석탄의 고품위화에 대한 연구가 관심의 대상이 되고 있다[1,2]. 그러나 저등급 석 탄의 수분을 건조하는 경우 자연발화의 위험성이 높아지고, 장기간 보관 시 다시 수분을 흡착하게 된다[3-5]. 따라서, 수 분을 건조 시 자연발화를 억제하며, 수분 흡착을 방지할 필요 가 있겠다. 일반적으로 석탄의 자연발화는 저온에서 석탄과 산소의 반응에 의해 일어난다고 알려져 있다[6,7]. 석탄과 산 
소가 비가역적 발열 반응을 하면 열이 발생되고 발생된 산화 열이 축적되면 자연발화가 촉진된다[8]. 석탄과 산소의 반응 은 다음의 3가지 방식으로 이루어진다고 알려져 있다[9]. (1) 산소의 물리적 흡착; (2) 석탄과 산소의 결합과 산화된 탄소 물질로의 화학적 흡착; (3) 석탄과 산소의 반응으로 $\mathrm{CO}, \mathrm{CO}_{2}$, 수증기와 같은 가스 물질이 발생되는 산화. 일반적으로 탄화 도가 낮은 저등급 석탄에서 자연발화 위험성이 높으며 석탄 의 등급이 높아질수록 자연발화 위험성은 낮아진다.[10]. 대 표적인 석탄의 고품위화 방법으로 저등급 석탄의 수분을 제 거하여 발열량을 높이고, 자연발화를 방지하기 위해 기공을 중질유로 막는 고품위 갈탄(upgrade brown coal, UBC)[1,18], 열과 압력을 가하여 물을 짜내는 열역학 익스프레션(mechanical thermal expression, MTE)[19] 등이 건조 안정화 기술로 사용 하고 있다. UBC 공정은 중질유를 액상에 녹여 흡착시키는 액 상 흡착방법으로 주로 등유를 용매로 사용하는데, 용매 가격 이 석탄의 4 배로 비싸고 용매의 사용량이 많아 경제성이 낮다. 그리고, MTE 공정은 유기물이 열분해 되면서 가연성분의 손 실이 많아지고 또한 탈수되는 과정에서 빠져나가는 수분에 상당량의 유기물질이 용해되어 나가기 때문에 폐수처리가 수 반되어야 한다.

본 연구에서는 인도네시아, 말레이시아 등지에서 많이 생 산되는 팜유의 부산물인 팜 잔사유를 이용하여 저등급 석탄 을 고품위화시키는 방법을 개발하였다. 팜 잔사유는 상온에 서 고상이지만 $50{ }^{\circ} \mathrm{C}$ 이상에서 쉽게 녹으며 점도가 매우 낮아 표면 코팅에 유리한 특성을 갖고 있다. 또한 높은 발열량을 가지고 있어 기존 석탄에 혼합했을 때 발열량을 높여주는 역 할을 기대할 수 있다. 그리고, 다른 중질유보다 저가로 구매 할 수 있으며, 특히 원료인 $\mathrm{PFAD}$ 는 비 식용이며 친환경적이 라는 강점도 갖추고 있다. 향후 인도네시아 현지에서 상용화 규모에 고품위탄을 활용할 경우, 다른 중질유에 비해 저가로 구매할 수 있고 석탄 건조를 전체시스템의 폐열을 활용하여 건조함으로써 비용을 저감시킬 경우 충분한 경제성이 나올거 라 예상된다.

팜 잔사유 함량에 따른 고품위화 석탄의 안정화 특성을 비 교하기 위해 자연발화 경향 및 수분 재흡착에 대한 분석을 수 행하였다. 자연발화 경향을 살펴보기 위해 CPT[11-13]를 측정 하였으며, 저온에서 산화 처리를 통한 가스 발생량의 측정과 산소의 화학 흡착량 측정을 통해 산소와의 반응성을 비교해 보았다. 수분 재흡착 현상을 검토하기 위해 고품위화 석탄을 각각 대기와 항온 항습조에 72 시간 동안 방치하며 수분 흡착 량을 측정하였다.

\section{2. 실험 방법}

\section{1. 시료준비}

실험에는 인도네시아산 갈탄인 에코탄을 사용하였다. 에코 탄은 수분함량이 약 $30 \mathrm{wt} \%$ 로 저등급 석탄에 속하며, 발열량 은 도착시료 기준으로 측정한 결과 $4,192 \mathrm{kcal} / \mathrm{kg}$ 이었다. 팜 잔사유는 인도네시아산 $\mathrm{PFAD}$ 를 이용하였다. 실험에 사용한 PFAD의 말레이시아팜정유회사협회(palm oil refiners association of Malaysia, PORAM) 표준 사양서[15]는 Table 2와 같다. 녹는점은 $42 \sim 60{ }^{\circ} \mathrm{C}$, 밀도는 $87.8{ }^{\circ} \mathrm{C}$ 에서 $0.85 \sim 0.90 \mathrm{~g} / \mathrm{cm}^{3}$, 인 화점은 $200{ }^{\circ} \mathrm{C}$ 이상이며, 물에 녹지 않는 특성을 가지고 있다. $\mathrm{PFAD}$ 의 온도에 따른 점도를 측정한 결과를 Figure 1에 나타 내었다. 점도 측정 장치는 DV-III Ultra (Brookfield Engineering, $\mathrm{USA})$ 를 사용하였다. 온도 $50{ }^{\circ} \mathrm{C}$ 에서 약 $15 \mathrm{cP}$ 로 매우 낮은 점도를 나타내고 있으며, 온도가 상승할수록 점도가 더욱 감 소한다. PFAD의 비점 분포를 AC SIMDIS 장치(AC Analytical Controls ${ }^{\circledR}$, USA)를 이용하여 ASTM D2887 방법[16]으로

Table 2. PORAM standard specifications for palm fatty acid distillate

\begin{tabular}{c|c}
\hline Parameter & Specification \\
\hline \hline Free fatty acid palmitic & $70 \% \min$ \\
\hline Saponifiable matter & $95 \% \min$ \\
\hline Moisture and impurity & $1.0 \% \max$ \\
\hline
\end{tabular}

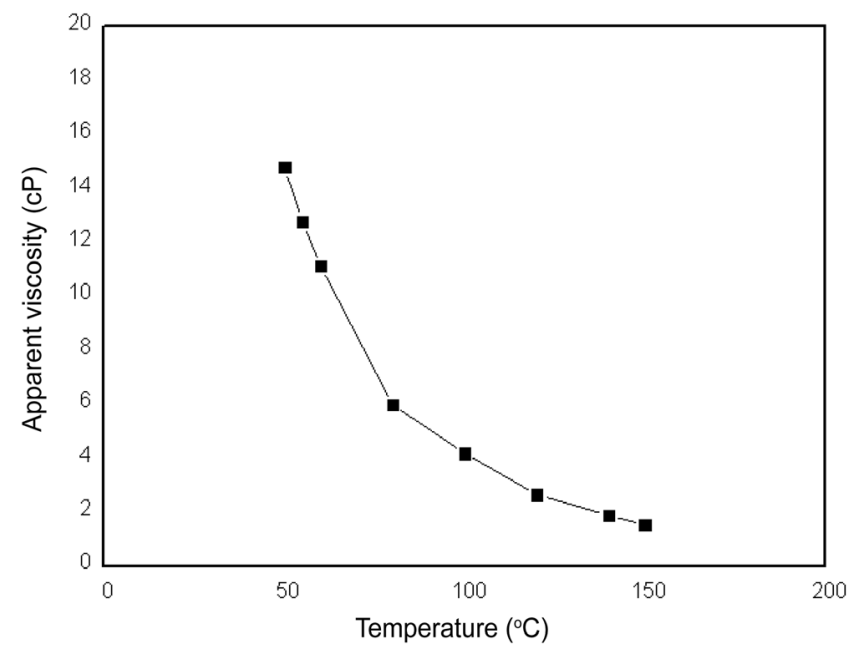

Figure 1. Viscosity of palm fatty acid distillate.

Table 1. Proximate, ultimate analysis and calorific value of Eco raw coal and upgraded coal (*: as received, **: dry)

\begin{tabular}{c|c|c|c|c|c|c|c|c|c|c}
\hline Sample (wt\%) & Moisture* & Volatile matter* & Ash* & Fixed carbon* & $\mathrm{C}^{* *}$ & $\mathrm{H}^{* *}$ & $\mathrm{O}^{* *}$ & $\mathrm{~N}^{* *}$ & $\mathrm{~S}^{* *}$ & Calorific value* $(\mathrm{kcal} / \mathrm{kg})$ \\
\hline \hline Raw & 29.95 & 36.57 & 4.27 & 29.21 & & & & & & \\
PFAD 0 & 0.35 & 53.68 & 5.73 & 40.23 & 67.60 & 4.61 & 20.74 & 1.16 & 0.14 & 4,192 \\
PFAD 5 & 0.12 & 58.72 & 4.85 & 36.30 & 69.80 & 5.16 & 18.96 & 1.12 & 0.09 & 5,912 \\
PFAD10 & 0.09 & 61.81 & 4.71 & 33.37 & 70.90 & 5.91 & 17.32 & 1.06 & 0.09 & 6,115 \\
PFAD20 & 0.56 & 64.19 & 3.88 & 31.37 & 71.70 & 6.63 & 16.67 & 1.00 & 0.08 & 6,509 \\
\hline
\end{tabular}




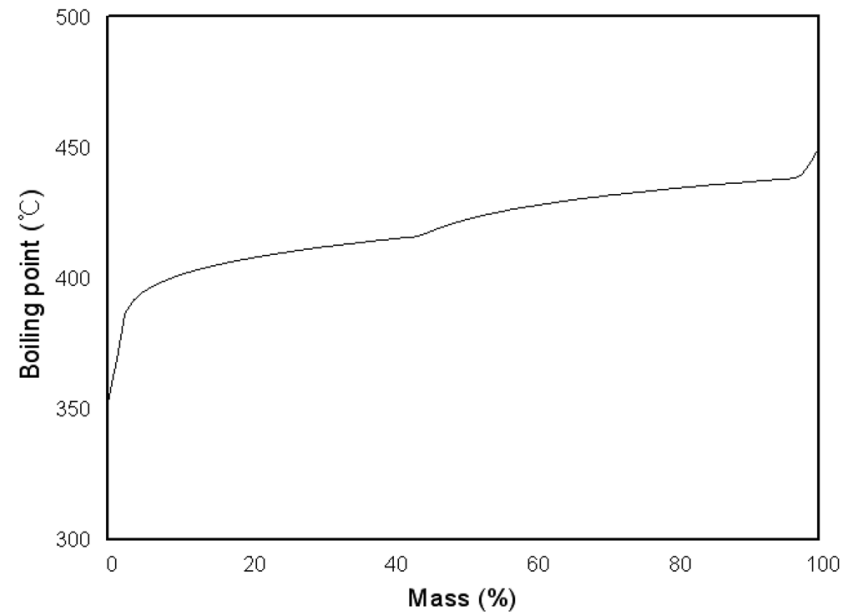

Figure. 2. True boiling point distribution by SIMDIS.

측정하였다. Figure 2에 나타낸 것과 같이 $\mathrm{PFAD}$ 의 비점은 350 $450{ }^{\circ} \mathrm{C}$ 로 매우 높은 값을 나타내었다. 발열량은 $9,256 \mathrm{kcal} / \mathrm{kg}$ 으로 측정되었다.

\section{2. 팜 잔사유를 혼합한 시료 제조}

석탄 제조는 인도네시아 갈탄인 에코탄을 분쇄 후 1 2 mm 로 입도 분리 하고 PFAD 0 20 wt\% 함량으로 혼합시켰다. $\mathrm{PFAD}$ 혼합 후 $107{ }^{\circ} \mathrm{C}$ 질소분위기로 전기오븐에서 12 시간 건 조하였다. 이 때 석탄의 기공에 있는 수분이 증발하면서 고체 상으로 혼합되어 있던 $\mathrm{PFAD}$ 가 융해하여 석탄 표면에 코팅된 다. $\mathrm{PFAD}$ 는 $107{ }^{\circ} \mathrm{C}$ 에서 점도가 매우 낮아져(Figure 1) 코팅에 유리한 조건을 갖는다. 건조된 석탄은 상온으로 자연 냉각되 며 표면에 코팅된 $\mathrm{PFAD}$ 가 다시 고상으로 응고된다. 고품위
화 석탄의 공업분석, 원소분석은 Table 1 과 같다. 분석기기는 TGA-701 Thermogravimeter, TruSpec Elemnatal Analyzer, SC432DR Sulfur Analyzer (LECO Co, USA)를 이용하였으며, 공 업분석과 원소분석 모두 건조기준으로 측정하였다. 발열량은 Parr 6400 Carlorimeter (Parr Co, USA)를 이용 하였다.

\section{3. 안정화 특성 평가}

석탄의 자연발화 특성을 평가하기 위한 측정에 사용된 실 험 장치는 오븐, 반응기 1 개, 가스 유량 조절기, 온도 데이터 저장장치로 구성되어 있다(Figure 4). 오븐 온도를 일정한 속 도로 증가시키면 석탄과 산소와의 반응열에 의해 반응기 내 부의 온도가 급격히 상승하면서 Figure 3과 같이 온도가 교차

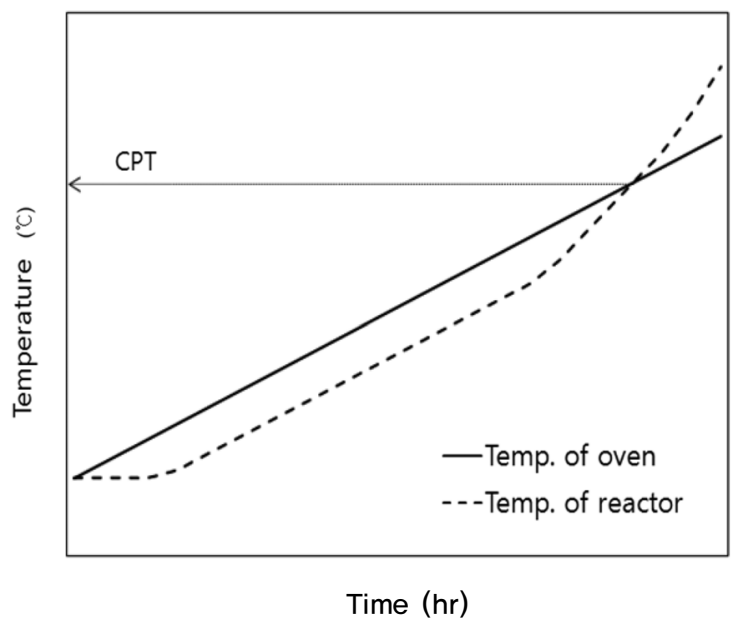

Figure 3. Principle of crossing-point temperature.

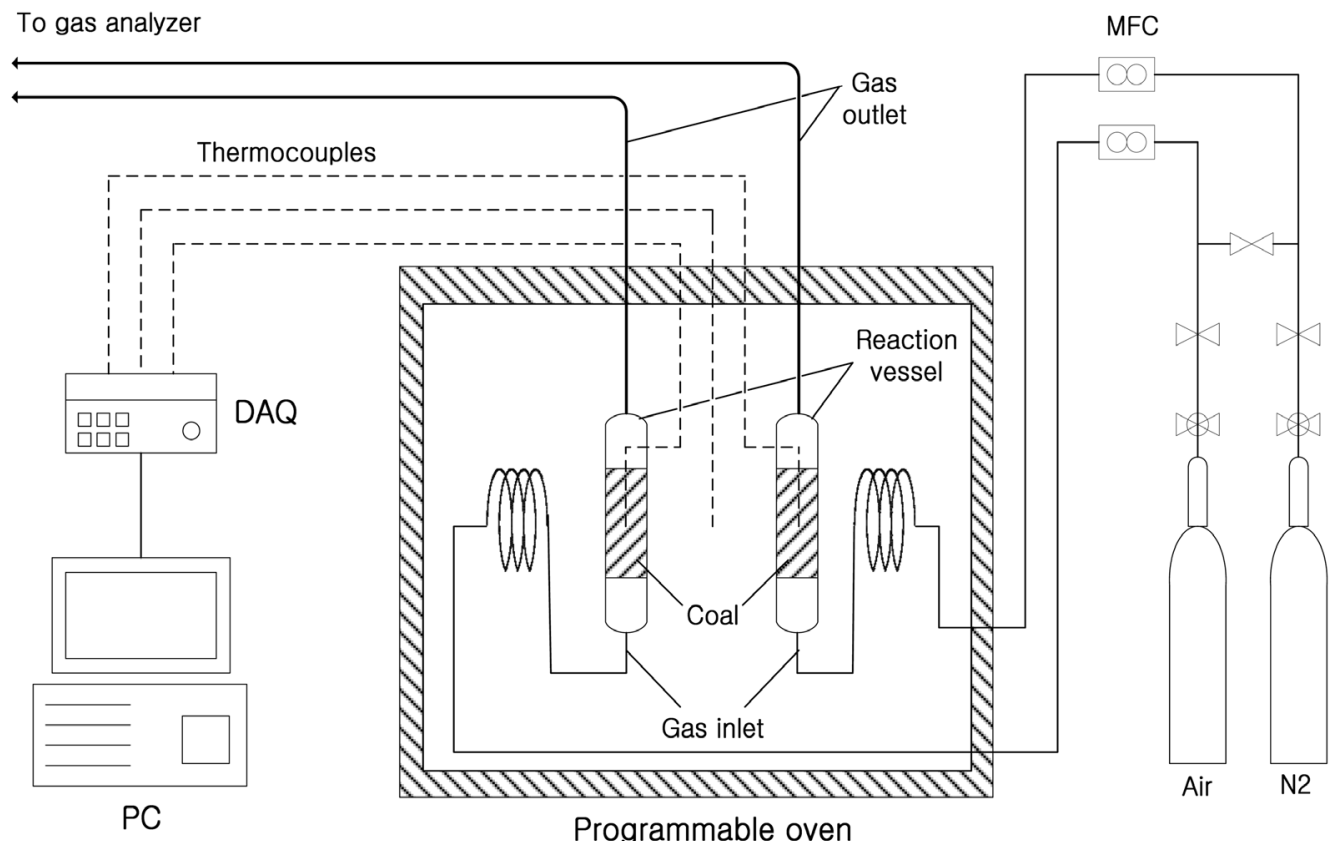

Figure 4. Experimental apparatus of crossing-point temperature analysis. 
하는 지점이 발생하는데 이를 CPT라 한다. CPT는 자연발화 경향을 나타내는 주요 척도로 $\mathrm{CPT}$ 가 높을수록 자연발화 경 향이 낮음을 의미한다. 온도는 각 반응기와 오븐에 삽입된 열 전대를 사용하여 측정하였다. 공급가스는 오븐 내부 온도와 맞추기 위해 오븐 내부의 동 나선(copper tube coil)을 통과시 켜 반응기로 공급하였다. 석탄시료를 반응기에 $35 \mathrm{~g}$ 잠입 후 질소가스를 $75 \mathrm{~mL} / \mathrm{min}$ 으로 유입시키면서 각각의 $40{ }^{\circ} \mathrm{C}$ 에서 2 시간 유지시켜 질소분위기로 안정화 시킨 후 분당 $0.5{ }^{\circ} \mathrm{C}$ 승 온 시키면서 $\mathrm{CPT}$ 를 측정하였다.

석탄의 발화점의 아래 온도에서 산화 여부를 판단하기 위 해 저온에서 산소와 반응하여 발생하는 가스를 분석하는 저온 산화 실험을 수행하였다[10]. 저온산화는 $35,70,100{ }^{\circ} \mathrm{C}$ 에서 각각 실시하였다. 석탄시료를 반응기에 $35 \mathrm{~g}$ 잠입 후 질소가 스를 $75 \mathrm{~mL} / \mathrm{min}$ 으로 유입시키면서 각각의 저온산화 온도에 서 2 시간 유지시켜 반응기 내 석탄시료의 온도와 오븐 온도 를 동일하게 맞췄다. 이후 질소를 동일 유량의 공기로 바꾼 후 저온산화 온도까지 승온 시킨 후 6시간 유지시켰다. 저온 산화 처리 중에는 오븐과 반응기 내부의 온도와 반응기를 통 해 배출되는 $\mathrm{CO}_{2}, \mathrm{CO}$ 농도를 15 분 간격으로 측정하였다. $\mathrm{CO}_{2}$, CO 농도는 XP 3180 (New cosmos electric, USA)을 사용하여 측정하였다. 가스 측정기 전단에는 응축 트랩을 달아 가스 내 수분을 제거하면서 측정 가스의 온도를 일정하게 유지시켰 다. 저온산화 실험 장치는 Figure 5 와 같다.

석탄과 산소와의 반응성을 평가하기 위하여 산소의 화학흡 착을 측정하였다. $107{ }^{\circ} \mathrm{C}$ 에서 72 시간 동안 질소 분위기로 전 처리한 석탄의 표면에 산소 가스의 부분 압을 $600 \mathrm{mmHg}$ 까지 1 시간 동안 서서히 증가시키면서 흡착량을 측정하였다 (1차 흡착). 이 때 측정된 값은 물리흡착과 화학흡착에 의한 흡착 량을 동시에 나타낸다. 산소가 흡착된 샘플을 진공 탈착 시킨 후 동일한 방법으로 산소를 흡착시켜 흡착량을 측정하였다 (2차 흡착). 흡착량의 측정은 ASAP 2020 (Micrometrics, USA) 을 이용하였으며, PFAD $0 \%$ 와 $10 \%$ 를 혼합한 고품위화 석탄 에 대해 $35{ }^{\circ} \mathrm{C}$ 와 $100{ }^{\circ} \mathrm{C}$ 에서 각각 측정하였다.

\section{4. 수분 재흡착 특성 평가}

저등급 석탄에 친수성 관능기가 고등급 석탄에 비해 많기 때문에 수분이 재 흡착되는 특성이 있다. $\mathrm{PFAD}$ 를 혼합하여 고품위화시킨 경우, 단순 건조 석탄에 비해 수분 재흡착 방지 되는데, 이를 확인하기 위해 건조된 석탄과 $\mathrm{PFAD}$ 를 혼합한 $0 \sim 20 \mathrm{wt} \%$ 석탄 $1 \mathrm{~g}$ 씩 대기방치 조건과 $30{ }^{\circ} \mathrm{C}$, 상대습도 $95 \%$ 의 항온 항습기 조건에서 각각 72 시간 동안 질량변화를 측정 하였다. 항온 항습기는 JEIO TECH사의 TH-I-300(1ph)을 사 용하였다.

\section{3. 실험 결과 및 고찰}

\section{1. 팜 잔사유가 혼합된 석탄의 물성 분석}

고품위화 석탄의 공업분석, 원소분석, 발열량 분석을 Table 1 에 나타내었다. 고품위화 석탄의 수분은 거의 대부분 증발 하였으며, PFAD 혼합에 의해 휘발분이 증가한 것으로 확인되 었다. 고품위화 석탄의 Van Krevelen 다이어그램[17]을 Figure 6 에 나타내었다. PFAD의 혼합량이 증가할수록 수소가 증가

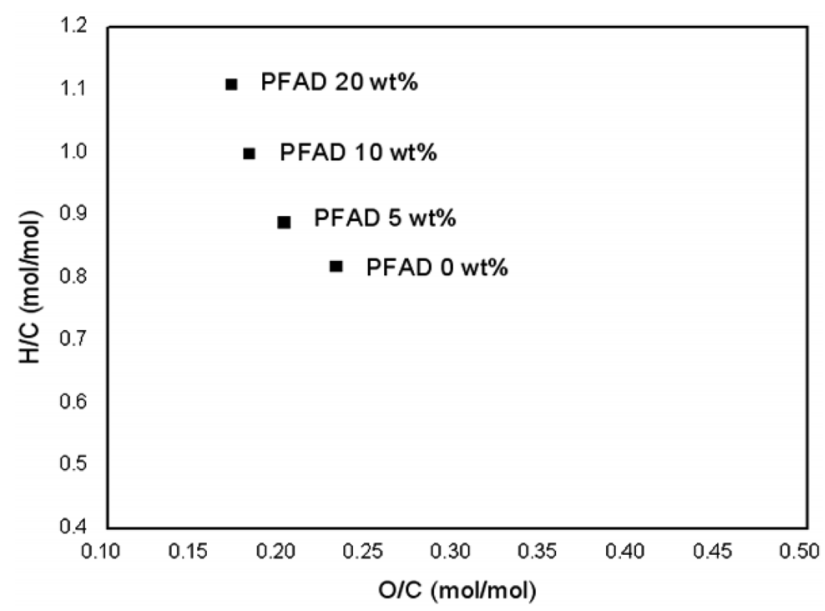

Figure 6. Van Krevelen diagram of upgraded coal.

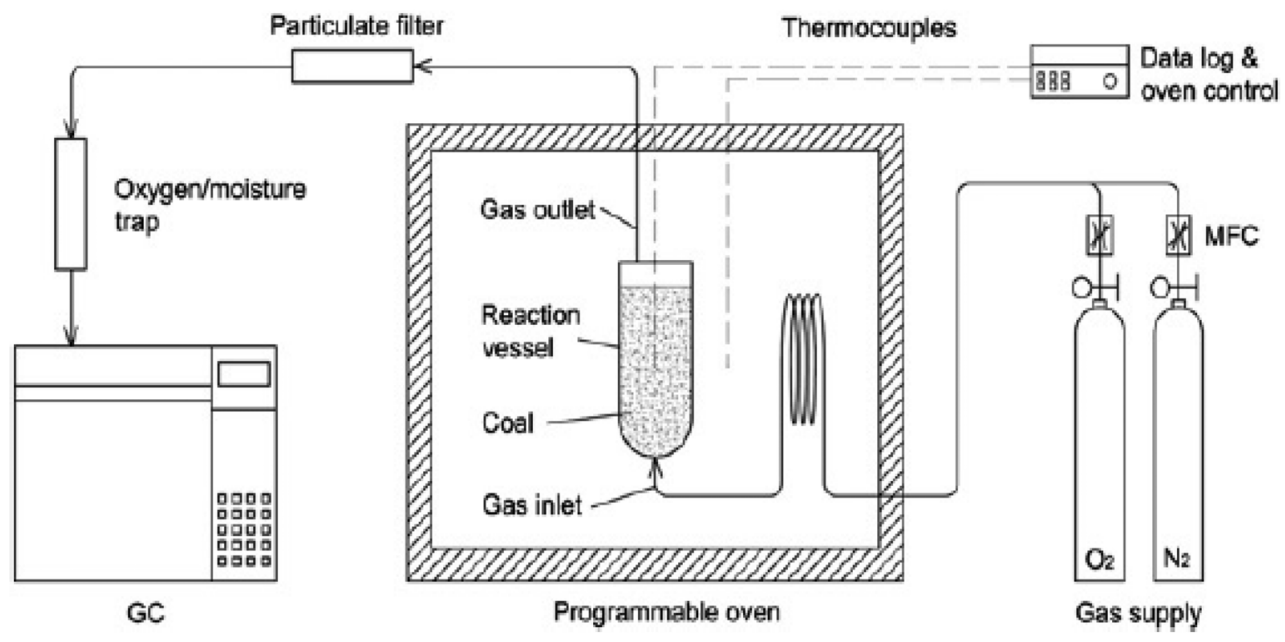

Figure 5. Experimental apparatus of isothermal oxidation gas analysis. 
하고 산소가 감소하여 발열량이 증가하는 방향으로 개질 되 는 것이 확인되었으며, 이는 Table 1에 나타낸 발열량 측정 결 과와 일치한다. Figure 6과 같은 현상은 $\mathrm{PFAD}$ 의 대부분을 차 지하고 있는 자유지방산의 원소가 대부분 탄소와 수소로 구 성되기 때문이다.

\section{2. 안정화 특성 평가 결과}

건조석탄과 고품위화석탄의 $\mathrm{CPT}$ 측정 결과를 Table 3 에 나 타내었다. 건조석탄의 CPT값보다 고품위화 한 석탄의 CPT값 이 증가 하는 것으로 보아 PFAD 혼합하여 건조한 시료가 자 연발화 경향이 감소하는 것을 확인하였다. 이는 단순 건조 석 탄보다 $\mathrm{PFAD}$ 를 혼합한 경우 $\mathrm{PFAD}$ 가 석탄 표면에 코팅되어 자연 발화를 억제하는 효과가 있다고 판단된다.

Table 3. Comparison of crossing-point temperature

\begin{tabular}{c|c}
\hline Sample name & CPT $\left({ }^{\circ} \mathrm{C}\right)$ \\
\hline \hline PFAD 0 wt $\%$ & 139 \\
\hline PFAD 5 $\mathrm{wt} \%$ & 146 \\
\hline PFAD 10 $\mathrm{wt} \%$ & 148 \\
\hline PFAD 20 $\mathrm{wt} \%$ & 149 \\
\hline
\end{tabular}
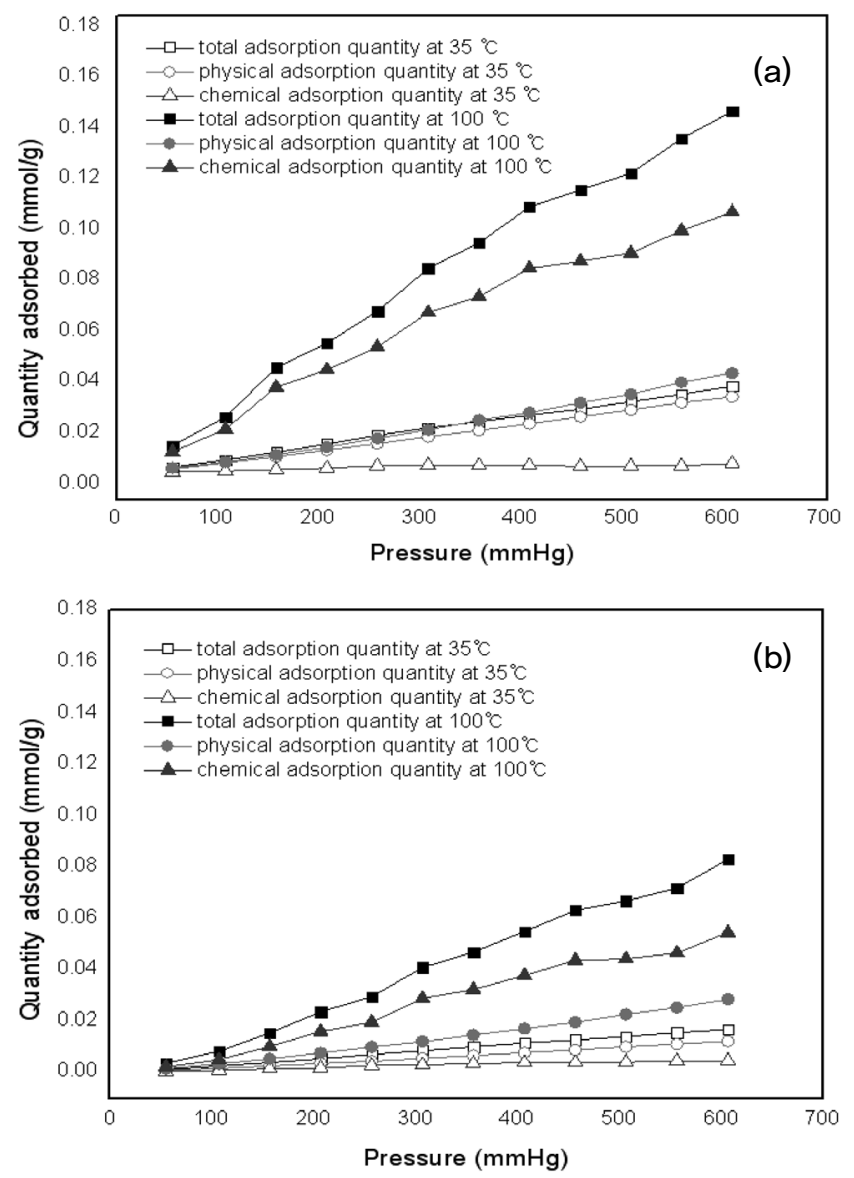

Figure 7. Chemical and physical adsorption quantity of (a) dried coal (b) upgraded coal.
산소 화학흡착 결과를 Figure 7에 나타내었다. 고품위화 석 탄은 $10 \mathrm{wt} \%$ 를 혼합한 경우에 대하여 측정하였다. 온도에 따 른 산소 흡착량 변화를 확인한 결과 $35{ }^{\circ} \mathrm{C}$ 에서는 건조석탄에 비해 고품위화 석탄의 물리 흡착량은 감소하였으나, 화학흡 착은 두 석탄 모두 거의 나타나지 않고 있다. 이는 $35{ }^{\circ} \mathrm{C}$ 에서 산소와의 반응성이 매우 낮음을 의미하며, 물리적인 비표면적 은 건조석탄에 비해 고품위화 석탄이 PFAD 코팅에 의해 감 소되었음을 나타낸다. 반면 $100{ }^{\circ} \mathrm{C}$ 에서는 건조석탄에 비해 고 품위화 석탄의 화학 흡착량이 감소하는 것을 확인하였다. 이 는 온도가 증가할수록 고품위화 석탄의 반응성이 건조석탄의 반응성에 비해 낮아지는 것을 의미한다.

저온산화의 결과를 Figure 8, 9에 나타내었다. $35{ }^{\circ} \mathrm{C}$ 조건에 서는 $\mathrm{CO}_{2}, \mathrm{CO}$ 가스가 거의 배출되지 않았으며, 온도가 상승할 수록 가스 배출량이 증가하는 것으로 나타났다. 또한, Figure 8에 보이듯이, 고품위화 석탄의 PFAD 함량이 증가할수록 가 스 배출량이 감소하는 것을 확인하였다. $70{ }^{\circ} \mathrm{C}$ 조건에서는 $\mathrm{CO}$ 가스가 6시간 동안 건조석탄에서만 배출되었고, 고품위화 석 탄에서는 가스가 배출되지 않았다. 그리고 $\mathrm{CO}_{2}$ 가스 배출양은 $\mathrm{PFAD} 20 \mathrm{wt} \%$ 혼합한 석탄이 건조석탄에 비해 $64 \%$ 감소되었 다(Figure 9). $100{ }^{\circ} \mathrm{C}$ 조건에서는 PFAD $20 \mathrm{wt} \%$ 혼합한 석탄의 $\mathrm{CO}, \mathrm{CO}_{2}$ 가스 배출양이 건조석탄 보다 각각 $76 \%, 71 \%$ 감소
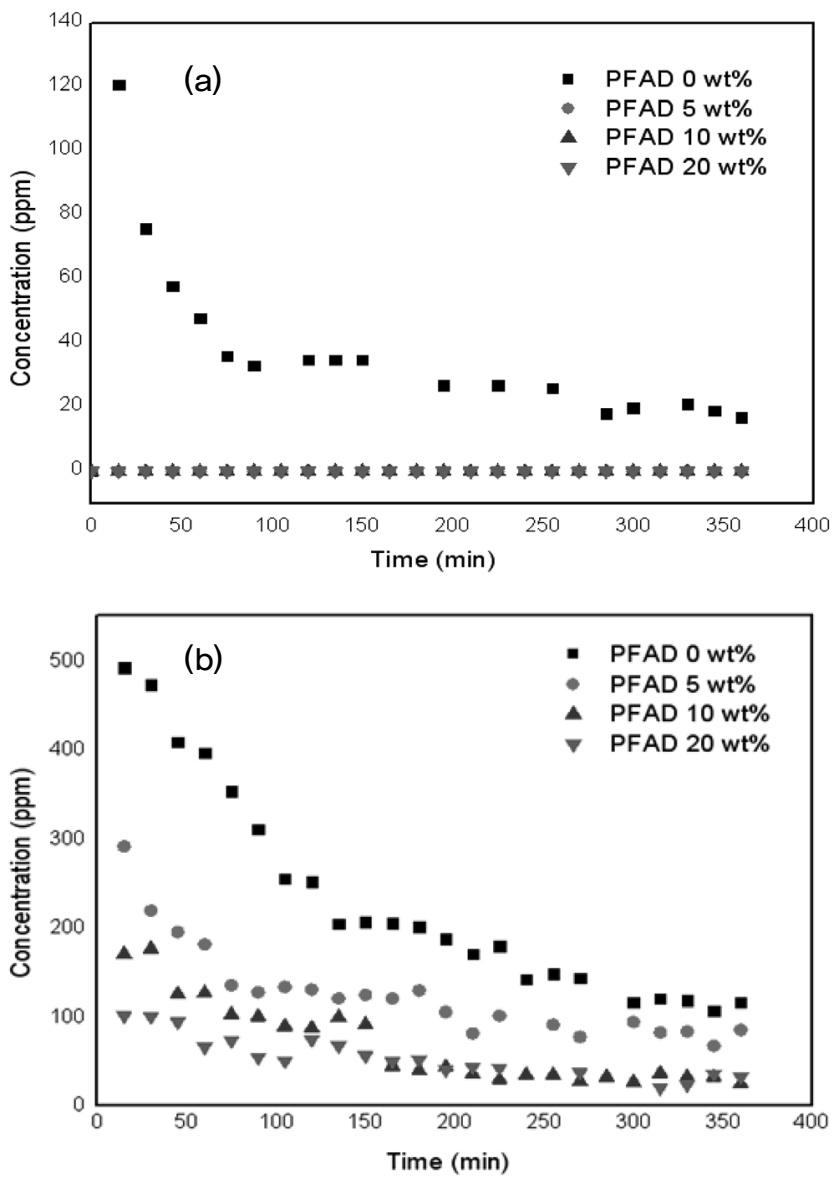

Figure 8. Concentration changes of $\mathrm{CO}$ at (a) $70{ }^{\circ} \mathrm{C}$, (b) $100{ }^{\circ} \mathrm{C}$. 

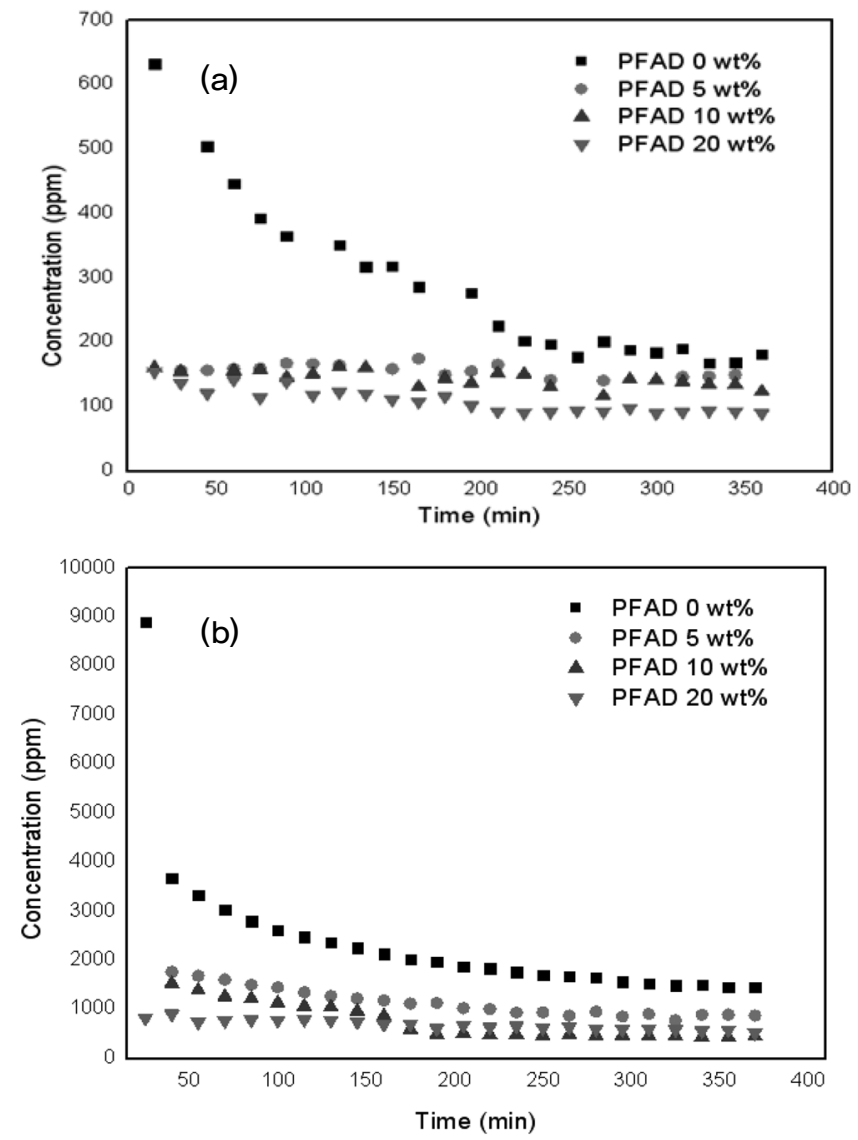

Figure 9. Concentration changes of $\mathrm{CO}_{2}$ at (a) $70{ }^{\circ} \mathrm{C}$, (b) $100{ }^{\circ} \mathrm{C}$.

하였다(Figure 8, 9). $\mathrm{PFAD}$ 를 혼합한 결과 $\mathrm{CO}, \mathrm{CO}_{2}$ 가스 배출 량이 $70{ }^{\circ} \mathrm{C}, 100{ }^{\circ} \mathrm{C}$ 모두 감소했고, $\mathrm{PFAD}$ 혼합을 통해 산화를 억제 시키는 효과가 있다고 할 수 있겠다.

\section{3. 수분 재흡착 평가 결과}

건조탄과 고품위화 석탄의 대기방치와 항온항습 $30{ }^{\circ} \mathrm{C}$, 상 대습도 $95 \%$ 에서 72 시간 동안 질량변화 측정한 결과를 Figure

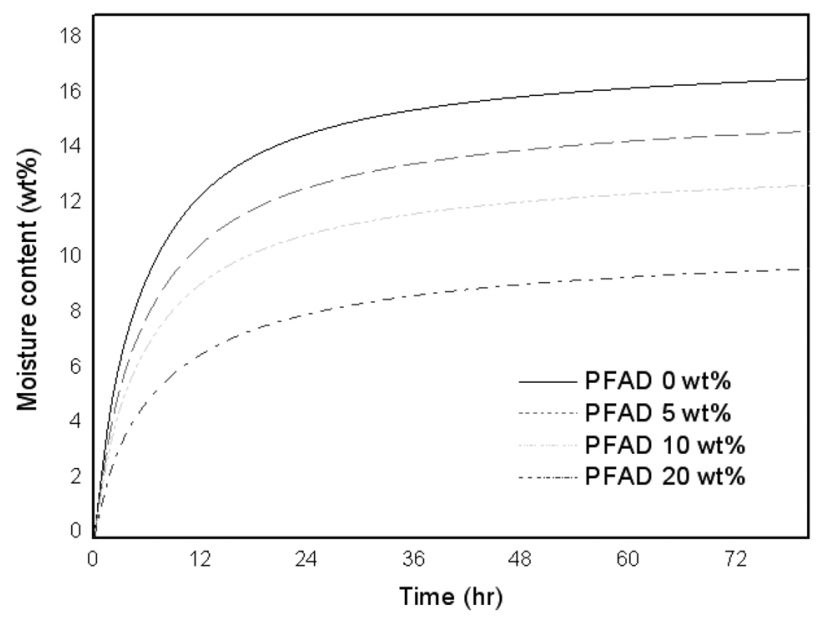

Figure 10. Moisture readsorption characteristics of upgraded coal at $30{ }^{\circ} \mathrm{C}$ and R.H $95 \%$.

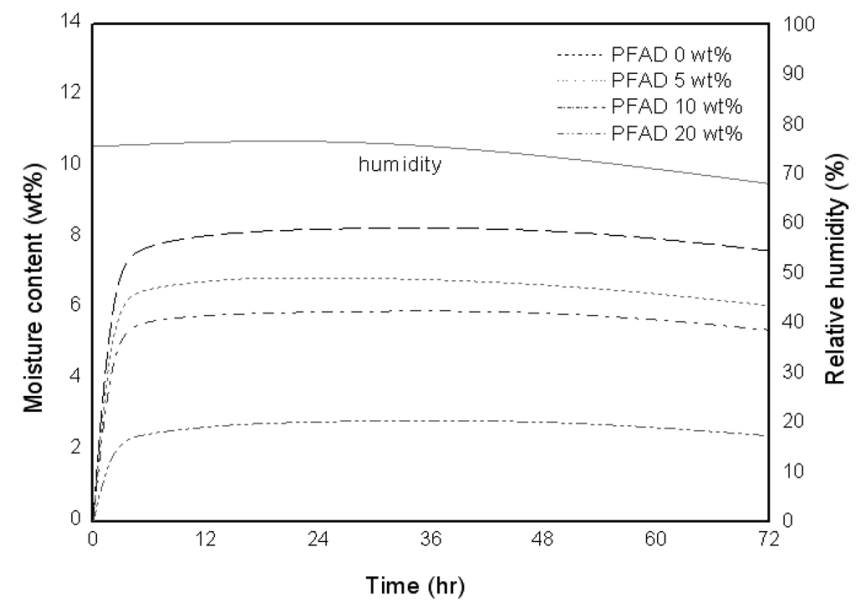

Figure 11. Moisture readsorption characteristics of upgraded coal under atmospheric exposure..

10,11 에 나타내었다. 대기방치 조건에서 습도에 따라 약간의 차이가 있었지만, 약 5 시간 후 수렴하는 경향을 보였다. 항온 항습조 분위기에서 대기 방치조건보다 열악한 조건에서 수분 을 얼마나 재흡착 하는지 확인하였다. 항온항습 분위기가 대 기방치 조건보다 수분 재흡착량이 약 2 배 증가하였다. 그리 고, 대기방치, 항온항습 모두 $\mathrm{PFAD}$ 함량이 증가 할수록 수분 재흡착량이 감소하였는데, PFAD $20 \mathrm{wt} \%$ 일 때 건조석탄에 비 해 대기방치 조건에서는 건조석탄 대비 $68 \%$, 항온항습 조건에 서는 $47 \%$ 감소하였다. 앞에서 언급한 것과 마찬가지로 PFAD 코팅에 대한 효과가 있다고 판단된다.

\section{4. 결 론}

본 연구에서는 저등급 석탄에 $\mathrm{PFAD}$ 를 이용해 고품위화 시 킨 석탄에 대한 안정화 특성을 알아보았다. 자연발화 특성을 알아보기 위해 측정한 $\mathrm{CPT}$, 저온산화, 산소화학흡착을 통해 $\mathrm{PFAD}$ 의 혼합으로 자연발화 경향이 감소한다는 것을 확인하 였다. 자연발화 경향이 감소하는 이유는 고품위화 석탄과 산 소와의 반응성이 낮아지기 때문인 것으로 확인 되었다. 또한, $\mathrm{PFAD}$ 의 함량이 높아질수록 자연발화 경향과 수분재흡착량 이 감소하여 안정화되는 것을 확인하였다. 하지만, PFAD도 석탄에 비해 고가의 물질이기 때문에 실제 공정에서는 원하는 품질로 고품위화 되도록 적정량을 혼합할 필요가 있다.

\section{감 사}

본 연구는 한국에너지기술연구원의 주요사업(KIER-GP20120005-05)의 지원을 받아 수행되었습니다.

\section{참고문헌}

1. Kinoshita, S., Yamamoto, S., Deguchi, T., and Shigehisa, T., "Demonstration of Upgraded Brown Coal (UBC) Process by 600 tonnes/days Plant," Kobelco Technol. Rev. 29, 93-98 (2010). 
2. Umar, D. F., Usui, H., and Daulay, B., "Change of Combustion Characteristics of Indonesian Low Rank Coal due to Upgraded Brown Coal Process," Fuel Proc. Technol., 87, 1007 (2006).

3. Mujumdar, A. S., and Jangam, S. V, "Drying of Low Rank Coal,” M3TC Technical Report2011.

4. Fei, Y., Aziz, A. A., Nasir, S., Jackson, W. R., Marshall, M., Hulston, J., and Chaffee, A. L., "The Spontaneous Combustion Behavior of Some Low Rank Coals and a Range of Dried Products," Fuel, 88, 1650-1655 (2009).

5. Unal, S., Wood, D. G., and Harris, I. J., "Effect of Drying Methods on the Low Temperature Reactivity of Victorian Brown Coal to Oxygen," Fuel, 71, 183-192 (1992).

6. Wang, D. M., Zhong, X. X., Gu, J. J., and Qi, X. Y., "Changes in Active Functional Groups during Low-temperature Oxidation of Coal," Mining Sci. Technol., 20, 35-40 (2010).

7. Brooks, K., Svanas, N., and Glasser, D. "Evaluating the Risk of Spontaneous Combustion in Coal Stockpiles," Fuel, 67, 651656 (1988).

8. Yuan, L., and Smith, A. C., "CO and $\mathrm{CO}_{2}$ Emissions from Spontaneous Heating of Coal under Different Ventilation Rates," Int. J. Coal Geol., 88, 24-30 (2011).

9. Carras, J. N., and Young, B. C., "Spontaneous Heating of Coal and Related Material: Models, Application and Test Methods," Prog. Energy Combust. Sci., 20, 1-15 (1994).

10. Jo, W. T., Choi, H. K., Kim, S. D., Yoo, J. H., Chun, D. H., Rhim, Y. J., Lim J. H., and Lee, S. H., "Surface Characteristics and Spontaneous Combustibility of Coal Treated with Non-polar Solvent under Room Temperature," Korean J. Chem. Eng, 51 (5), 609-614 (2013).
11. Xuyao, Q., Wang, D. M., Milke, J. A., and Zhong, X. X., "Crossing Point Temperature of Coal," Mining Sci. Technol., 21, 255-260 (2011).

12. Behera, P. and Mohanty, G., "Peroxy Complex and Crossing Point Temperature of Talcher Coals-An Adducer to Assess the Spontaneous Combustibility Character," J. Scientific Res., 1, 55-60 (2009).

13. Kadioglu, K. Y., and Gulaboglu, M. S., "A Study of Spontaneous Combustion Characteristics of a Turkish Lignite: Particle Size, Moisture of Coal, Humidity of Air," Combust. Flame, 133, 255-261 (2003).

14. Franceschetti, A. Pennycook, S. J., and Pantelides, S. T., "Oxygen Chemisorption on Au Nanoparticles," Chem. Physics Letters, 374, 471-475 (2003).

15. Ab Gapor Md Top, "Production and Utilization of Palm Fatty Acid Distillate (PFAD)," Lipid Technol., 22, 11-13 (2010).

16. Wang, C., and Firor, R., "Simulated Distillation System for ASTMD2887, Based on the Agilent 6890N GC," Agilent Technologies, 5989-2726EN (2005).

17. Toru Sugita, et al, "UBC (Upgraded Brown Coal) Process Development," Kobe Steel Eng. Reports, 53(2), 4-25 (2003).

18. Janine Hulston, George Favas, and Alan L. Chaffee, "PhysicoChemical Properties of Loy Yang Lignite Dewatered by Mechanical Thermal," Fuel, 84, 1940-1948 (2005).

19. Hulston, J., Favas, G., and Chaffee, A. L. "Physico-chemical Properties of Loy Yang Lignite Dewatered by Mechanical Thermal," Fuel, 1940-1948 (2005). 